IKONOMIKA: Journal of Islamic Economics and Business

Volume 2, No I (2017)

ISSN: 2527-3434 (PRINT) - ISSN: 2527-5I43 (ONLINE)

Page : $63-74$

\title{
Penerapan Dinar dan Stabilitas Ekonomi: Pendekatan Vector Autoregression
}

\author{
Aam Slamet Rusydiana \\ SMART Consulting
}

aamsmart@gmail.com

\begin{abstract}
The application of fiat money in transaction makes unstability in economy. To solve this problem, it needs a strong monetary system that support by stabil currency. This research is going to analyze the impact of dinar on economic stability in Indonesia. This study use vector error correction model as tool of analysis. The result shows that exchange rate had negative impat of economic growth, but dinat give a positive impact on economic growth. Besides that, the dinar doesn't give an impact on inflation increasing in Indonesia. This result imply that the application of dinar will make an economy relatively stabil than fiat money currency.
\end{abstract}

Keywords: Dinar, Economic Stability, Vector Error Correction Model

\begin{abstract}
Abstrak
Penggunaan uang fiat dalam transaksi menjadikan ekonomi tidak stabil. Untuk mengatasi hal tersebut, diperlukan adanya sebuah sistem moneter yang ditopang oleh sebuah mata uang yang stabil. Penelitian ini akan mencoba melihat pengaruh penerapan mata uang emas (dinar) terhadap stabilitas ekonomi di Indonesia. Teknik analisis yang dipergunakan ialah model koreksi kesalahan. Hasil penelitian menunjukkan bahwa variabel nilai tukar rupiah berpengaruh negatif terhadap pertumbuhan ekonomi, namun variabel dinar justru berpengaruh positif terhadap pertumbuhan ekonomi. Selain itu, penerapan dinar tidak memberikan dampak terhadap peningkatan inflasi di Indonesia. Hal ini menunjukkan bahwa penerapan dinar akan menjadikan perekonomian relatif lebih stabil.
\end{abstract}

Kata Kunci: Dinar, Stabilitas Ekonomi, Model Koreksi Kesalahan 


\section{A. PENDAHULUAN}

Uang adalah benda yang memiliki peranan penting dalamkehidupan manusia. Uang mempermudah manusia untuk saling memenuhikebutuhan hidup dengan cara melakukan pertukaran dan perdagangan barang danjasa. Selain itu, uang berfungsi sebagai alat pengukur nilai dan alat penyimpanankekayaan. Dalam skala global, uang memiliki peranan penting dalam aktifitasperekonomian dunia. Uang menjadi media pertukaran barang dan jasainternasional serta uang menjadi dasar dari sistem moneter dunia.Salah satu bentuk uang emas yang digunakan dalam sistem moneter duniaadalah uang dinar. Uang dinar berasal dari masa Romawi yang kemudiandigunakan oleh pemerintahan Islam. Uang dinar berfungsi sebagai alat tukar,pengukur nilai dan alat pembayaran. Uang dinar adalah uang yang stabil karenaterbuat dari logam mulia yang merupakan salah satu sumber daya alam yangsangat bernilai. Uang dinar tidak hanya memiliki nilai nominal tetapi jugamemiliki nilai intrinsik sebagai emas yang berharga.

Saat ini, sistem perdagangan dan moneter dunia menggunakan uang fiat. Uangfiat adalah uang yang nilai nominalnya tidak sama dengan nilai intrinsik dari uangtersebut, seperti uang kertas yang digunakan saat ini. Ketika uang fiat tersebutdijadikan sebagai kertas hampa biasa, maka uang fiat tersebut tidak akan bernilaisama sekali. Kehadiran uangfiat dalam sistem moneter dan perdagangan dunia telah menimbulkan berbagaipermasalahan, seperti terjadinya inflasi, menurunnya nilai daya beli uang, krisiskeuangan dunia, ketimpangan ekonomi, risiko nilai tukar dalam perdagangan internasional dan penguasaan perekonomian dunia oleh negara-negara maju khususnya negara yang memiliki nilai tukar mata uang yang kuat.

Untuk mengatasi hal tersebut, diperlukan adanya sebuah sistem moneter danperekonomian yang ditopang oleh sebuah mata uang yang stabil. Uang dinarmerupakan uang yang bernilai stabil dan memiliki nilai intrinsik sebagai logammulia dan nilai nominal sebagai uang yang berlaku. Selama penggunaannya, uangdinar dinilai lebih stabil dan memiliki tingkat inflasi yang sama dengan nol.

Dalam perdagangan internasional uang dinar berperan untuk memberikankemudahan untuk melakukan perdagangan, karena uang dinar terbuat dari emasyang nilainya sama di setiap negara, sehingga tidak akan ada perbedaan nilainyadisetiap negara yang menggunakannya. Penggunaan uang dinar dalamperdagangan akan mengurangi berbagai hambatan yang terjadi dalamperdagangan internasional, seperti praktik spekulasi, arbitrasi, resiko perubahannilai tukar, dan hambatan lainnya. 
Untuk menjadikan dinar sebagai mata uang yang digunakan sebagai dasar darisistem moneter dunia, diperlukan berbagai langkah dan startegi untuk bisamewujudkan hal tersebut. Salah satu langkah dan strategi yang dilakukan adalahdengan menerapkan uang dinar dalam perdagangan internasional terutama padaperdagangan ekspor dan impor antara negara-negara Muslim, tetapi tidak tertutupkemungkinan dinar bisa diterapkan dalam perdagangan dengan negara nonMuslim. Penggunaan uang dinar dalam transaksi perdagangan telah dilakukan olehpemerintah Malaysia pada tahun 2002 dengan mitra dagangnya seperti Iran danArab Saudi. Disamping itu, penggunaan uang dinar dalamperdagangan internasional akan mengurangi dominasi dan ketergantungan negara-negara muslim dan negara berkembang terhadap uang fiat seperti dollar, euro, yendan uang fiat lainnya.Penggunaan uang dinar yang telah dilakukan oleh pemerintah Malaysiamerupakan salah satu solusi dan strategi perdagangan yang bisa dilakukan danditerapkan oleh negara muslim dan negara berkembang lainya.

Uang dinar merupakan uang yang pernah digunakan sebagai alat transaksidan dasar moneter global. Mengembalikan uang dinar sebagai alattransaksi dan dasar sistem moneter global merupakan suatu usaha untukmewujudkan sistem moneter yang stabil. Apakah penerapan dinar dalam sistem moneter akan mampu memberikan kestabilan ekonomi?

Penerapan uang dinar dalam perdagangan akan menggantikan peran dariuang fiat, serta akan mengurangi ketergantungan negara-negara yangsedang berkembang terhadap uang fiat untuk melakukan transaksiperdagangan luar negeri. Jika dibandingkan dengan mata uang rupiah, manakah diantara keduanya yang relatif memberikan dampak positif terhadap stabilitas ekonomi suatu Negara?

Penerapan uang dinar dalam perdagangan tentunya akan mempengaruhi sistem pembayaran dan sistem moneter (termasuk Indonesia) yang selanjutnya akan berdampak pada variabel makro penting seperti PDB dan Inflasi. Secara detail, bagaimanakah dampak kurs rupiah (uang fiat) dan mata uang emas (dinar) terhadap kedua variabel makro tersebut?

\section{B. METODE}

Data yang digunakan dalam studi ini adalah data sekunder berupa time series yang didapat dari Badan Pusat Statistik (BPS).Data-data tersebut adalah nilai Produk Domestik Bruto (PDB) dan nilai inflasi sebagai proksi pertumbuhan dan stabilitas ekonomi, dan data harga emas per gram dalam rupiah sebagai proksi variabel dinar. Sementara data nilai tukar kurs rupiah atas dolar Amerika diunduh dari Statistika Ekonomi dan Keuangan Indonesia pada Bank Indonesia (SEKI-BI). 
Seluruh data dimulai dari periode kuarter pertamatahun 2006 hingga kuarter keempat 2015.

Permasalahan dalam studi ini akan dianalisis dengan memakai Vector Autoregression. Secara sederhana, VAR menggambarkan hubungan yang "saling menyebabkan" (kausalistis) antarvariabel dalam sistem, dengan menambahkan intercept. Metode ini mulai dikembangkan oleh Sims pada tahun 1980 (Hasanah, 2007) yang mengasumsikan bahwa semua variabel dalam model bersifat endogen (ditentukan di dalam model) sehingga metode ini disebut sebagai model yang ateoritis (tidak berdasar teori).

Apabila data yang digunakan stasioner pada perbedaan pertama maka modelVAR akan dikombinasikan dengan model koreksi kesalahan menjadi Vector ErrorCorrection Model (VECM). Analisis impulse response function dilakukan untukmelihat respon suatu variabel endogen terhadap guncangan variabel lain dalam model.Variance decomposititon analysis juga dilakukan untuk melihat kontribusi relatif suatuvariabel dalam menjelaskan variabilitas variabel endogenusnya. Semua data dalampenelitian ini ditransformasikan ke dalam bentuk logaritma natural (ln) untuk mendapatkan hasil analisisyang lebih valid dan konsisten. VECM adalah bentuk Vector Autoregression yang terestriksi. Restriksi tambahan ini harus diberikan karena keberadaan bentuk data yang tidak stasioner namun terkointegrasi. VECM kemudian memanfaatkan informasi restriksi kointegrasi tersebut ke dalam spesifikasinya. Karena itulah VECM sering disebut desain VAR bagi series nonstasioner yang memiliki hubungan kointegrasi.

Setelah diketahui adanya kointegrasi maka proses uji selanjutnya dilakukan dengan menggunakan metode error correction. Jika ada perbedaan derajat integrasi antarvariabel uji, Setiawan (2007) menyarankan agar pengujian dilakukan secara bersamaan (jointly) antara persamaan jangka panjang dengan persamaan error correction, setelah diketahui bahwa dalam variabel terjadi kointegrasi. Perbedaan derajat integrasi untuk variabel yang terkointegrasi disebut (sebagai multicointegration. Namun jika tidak ditemui fenomena kointegrasi, maka pengujian dilanjutkan dengan menggunakan variabel first difference.

Dalam melakukan analisisnya, VAR memiliki instrumen spesifik yang memiliki fungsi spesifik dalam menjelaskan interaksi antarvariabel dalam model. Instrumen itu meliputi Impulse Response Function (IRF) dan Forecast Error Variance Decompisitions (FEVD), atau biasa disebut Variance Decompisitions (VD). IRF merupakan aplikasi vector moving average yang bertujuan melihat seberapa lama goncangan dari satu variabel berpengaruh terhadap variabel lain. 
Sedangkan VD dalam VAR berfungsi untuk menganalisis seberapa besar goncangan dari sebuah variabel mempengaruhi variabel lain.

\section{HASIL DAN PEMBAHASAN}

Metoda pengujian yang digunakan untuk melakukan uji stasioneritas data dalam penelitian ini adalah uji ADF (Augmented Dickey Fuller) dengan menggunakan taraf nyata lima persen. Jika nilai t-ADF lebih kecil dari nilai kritis MacKinnon, maka dapat disimpulkan bahwa data yang digunakan adalah stasioner (tidak mengandung akar unit).

Tabel I

Hasil Uji Akar Unit

\begin{tabular}{|c|c|c|c|c|}
\hline \multirow{2}{*}{ Variabel } & \multicolumn{2}{|c|}{ Nilai ADF } & \multicolumn{2}{|c|}{ Nilai Kritis McKinnon 5\% } \\
\hline & Level & Ist Difference & Level & Ist Difference \\
\hline LNPDB & -2.017662 & -5.725297 & 3.470032 & -I.945I99 \\
\hline LNINF & $-4.4235 \mathrm{I} 3$ & -II.42053 & 3.470032 & -1.945199 \\
\hline LNKURS & -3.434638 & $-\mathrm{I} 0.4542 \mathrm{I}$ & 3.470032 & $-\mathrm{I} .945 \mathrm{I} 99$ \\
\hline LNGOLD & -2.378988 & -3.431635 & $3.47085 \mathrm{I}$ & -1.945199 \\
\hline
\end{tabular}

Catatan: Cetak tebal menunjukkan bahwa data tersebut stasioner pada taraf 5\%

Pengujian akar-akar unit ini dilakukan pada tingkat level sampai dengan first difference. Variabel-variabel yang digunakan dalam penelitian ini ada yang stasioner dan ada pulayang tidak stasioner pada tingkat level. Setelah dilakukan first difference barulah semuadata stasioner pada taraf nyata lima persen. Artinya data yang digunakan pada penelitian ini terintegrasi pada ordo satu atau dapat disingkat menjadi I(I). Variabel yang telah stasioner pada tingkat level adalah nilai inflasi (LNINF). Sementara yang lain baru mengalami stasioner pada first difference. Hasil pengujian akar unit dapat dilihat pada Tabel I.

Pengujian panjang lag optimum ini sangat berguna untuk menghilangkan masalah autokorelasi dalam sistem VAR. Sehingga dengan digunakannya lag optimal diharapkan tidak muncul lagi masalah autokorelasi. Penentuan lag optimal yang digunakan dalam penelitian ini berdasarkan lag terpendek dengan menggunakan Schwatz Information Criterion (SC). Hasilnya menunjukkan bahwa model mengalami lag optimal pada lagI. 
Tabel 2

Hasil Uji Lag Optimum

\begin{tabular}{|c|c|c|c|c|c|c|}
\hline Lag & Log $L$ & LR & FPE & AIC & SC & $\mathrm{HQ}$ \\
\hline 0 & 66.47989 & NA & $6.27 \mathrm{e}-09$ & -1.860920 & $-\mathrm{I} .660207$ & $-1.78 I 726$ \\
\hline I & I 46.0777 & I42.05I6 & I.65e-09 & -3.202392 & $-1.797403^{*}$ & -2.648034 \\
\hline 2 & 205.3752 & 94.87592 & $8.27 \mathrm{e}-\mathrm{I0}$ & -3.919237 & -I.309972 & $-2.889714^{*}$ \\
\hline 3 & 252.9674 & 67.36126 & $\begin{array}{r}6.22 \mathrm{e}-10 \\
5.60 \mathrm{e}-\end{array}$ & -4.275920 & -0.462379 & -2.771233 \\
\hline 4 & 297.I2I8 & 54.34390 & $10^{\text {* }}$ & -4.526825 & 0.490992 & -2.546974 \\
\hline 5 & 329.9368 & 34.32949 & $7.96 \mathrm{e}-10$ & -4.428823 & I.793270 & -I.973809 \\
\hline 6 & 385.4783 & 47.85119 & $6.65 \mathrm{e}-\mathrm{I0}$ & $-5.030102^{*}$ & 2.396267 & -2.099923 \\
\hline
\end{tabular}

Catatan: Tanda asterik $\left({ }^{*}\right)$ menunjukkan SC terkecil

Stabilitas VAR perlu diuji terlebih dahulu sebelum melakukan analisis lebih jauh, karena jika hasil estimasi VAR yang akan dikombinasikan dengan model koreksi kesalahan tidak stabil, maka Impulse Response Function dan Variance Decomposition menjadi tidak valid (Gujarati dan Porter, 2009). Untuk menguji stabil atau tidaknya estimasi VAR yang telah dibentuk maka dilakukan pengecekan kondisi VAR stability berupa roots of characteristic polynomial. Suatu sistem VAR dikatakan stabil apabila seluruh roots-nya memiliki modulus lebih kecil dari satu (Gujarati dan Porter, 2009). Berdasarkan uji stabilitas VAR, dapat disimpulkan bahwa estimasi VAR yang akan digunakan untuk analisis IRF dan VD stabil. Ringkasan uji stabilitas VAR dapat dilihat pada Tabel 3. Dari tabel tersebut dapat diambil kesimpulan bahwa model VAR yang dibentuk sudah stabil pada lag optimalnya.

Tabel 3

Hasil Uji Stabilitas VAR

\begin{tabular}{cccc}
\hline Model & Kisaran Modulus & Kisaran Modulus & Kisaran Modulus \\
\hline \multirow{6}{*}{ Lag 7 } & 0.969347 & 0.884954 & 0.828583 \\
& 0.969347 & 0.880867 & 0.828583 \\
& 0.940056 & 0.880867 & 0.804156 \\
& 0.940056 & 0.879440 & 0.645944 \\
& 0.937806 & 0.879440 & 0.645944 \\
& 0.937806 & $0.86566 \mathrm{I}$ & 0.500247 \\
& 0.923824 & $0.86566 \mathrm{I}$ & 0.500247 \\
& 0.923824 & 0.859634 & 0.010429 \\
& 0.905197 & 0.842083 & 0.010413 \\
& 0.905197 & 0.842083 & 0.010413 \\
\hline
\end{tabular}




\begin{tabular}{ccc}
\hline $0.90 \mathrm{I} 538$ & 0.832658 & $0.0 \mathrm{I} 0377$ \\
$0.90 \mathrm{I} 538$ & 0.832658 & 0.010377 \\
$0.8925 \mathrm{II}$ & 0.828727 & $0.01035 \mathrm{I}$ \\
$0.8925 \mathrm{II}$ & 0.828727 & $0.01035 \mathrm{I}$ \\
\hline
\end{tabular}

Pengujian ini dilakukan dalam rangka memperoleh hubungan jangka panjang antarvariabel yang telah memenuhi persyaratan selama proses integrasi yaitu dimana semua variabel telah stasioner pada derajat yang sama yaitu derajat I I(I). Informasi jangka panjang diperoleh dengan menentukan terlebih dahulu rank kointegrasi untuk mengetahui berapa sistem persamaan yang dapat menerangkan dari keseluruhan sistem yang ada.

Setelah melalui serangkaian uji pra-estimasi, yakni uji akar unit, penentuan optimum lag, uji stabilitas VAR hingga uji kointegrasi, dan faktanya terdapat satu rank kointegrasi pada taraf nyata lima persen dalam model ini, maka penghitungan dilanjutkan pada tahap selanjutnya yakni VECM. Estimasi VECM dilakukan untuk melihat analisis jangka panjang dan pendek. Berikut ini disajikan simulasi analisis Impulse Response.

Rangkuman hasil analisis Impulse Response Function untuk pengaruh dinar dan nilai tukar rupiah terhadap stabilitas ekonomi di Indonesiadapat dibaca pada tabel 4.

Tabel 4

Respon PDB dan Inflasi

\begin{tabular}{ll}
\hline \multicolumn{1}{c}{ Model Islam } & \multicolumn{1}{c}{ Respon Variabel Stabilitas Ekonomi } \\
\hline Guncangan Kurs thd & Negatif dan permanen -0.004, stabil mulai periode ke- \\
PDB & 7 \\
Guncangan Kurs thd & \\
Inflasi & Positif dan permanen 0.00I, stabil mulai periode ke-6 \\
Guncangan Emas thd & \\
PDB & $\begin{array}{l}\text { Positif dan permanen 0.007, stabil mulai periode ke-I I } \\
\text { Guncangan Emas thd }\end{array}$ \\
Inflasi & $\begin{array}{l}\text { Negatif dan permanen -0.00I, stabil mulai periode ke- } \\
\text { II }\end{array}$ \\
\hline
\end{tabular}

Tabel 4. menunjukkan bahwa respon PDB dan Inflasi terhadapguncangan variabel lainnya berfluktuasi, baikoleh variabel kurs maupun emas. Sementara jika kita melihat Gambar I yang merupakan gambaran respon PDB terhadap guncangan beberapa variabel KURS dan GOLD, kita dapat mencermati bahwa PDB merespon negatif0.004 persen terhadapguncangan variabel KURS (nilai mata uang rupiah) sebesar satu standar deviasi. Sedangkan guncangan padavariabel GOLD (nilai emas sebagai proksi variabel dinar) direspon positif dan permanen oleh PDB.Produk 
domestic bruto sebagai variabel inti pertumbuhan dan stabilitas ekonomi dapat dikatakan stabil dalam merespon guncangan KURS setelahperiode ke-7, sementara PDB mulaistabil dalam merespon guncangan GOLD pada periode ke-II dengan responsebesar 0.007 persen.

\section{Gambar I}

\section{Respon PDB terhadap Variabel KURS dan GOLD}

Response to Cholesky One S.D. Innovations
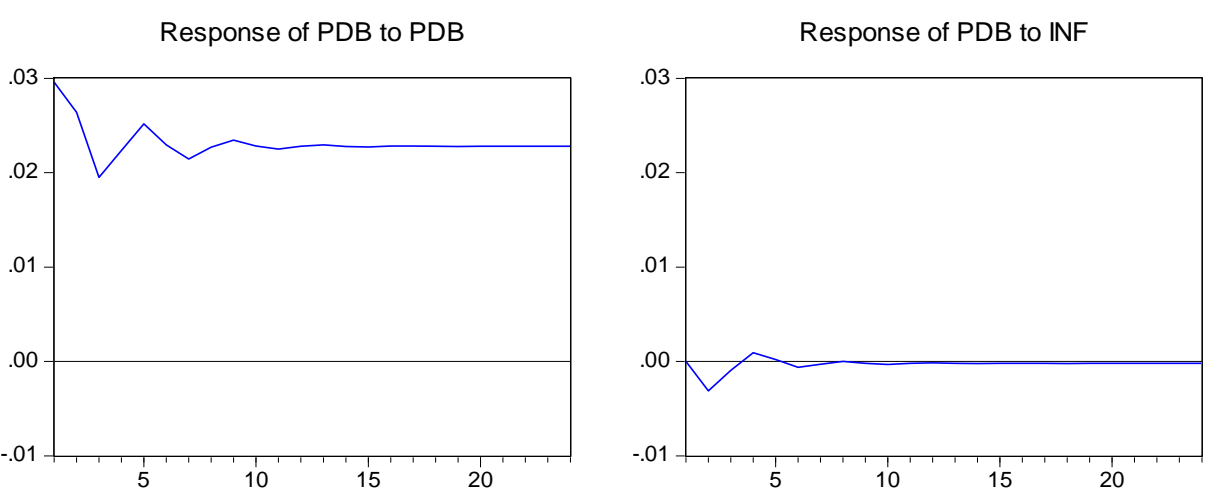

Response of PDB to GOLD

Response of PDB to KURS
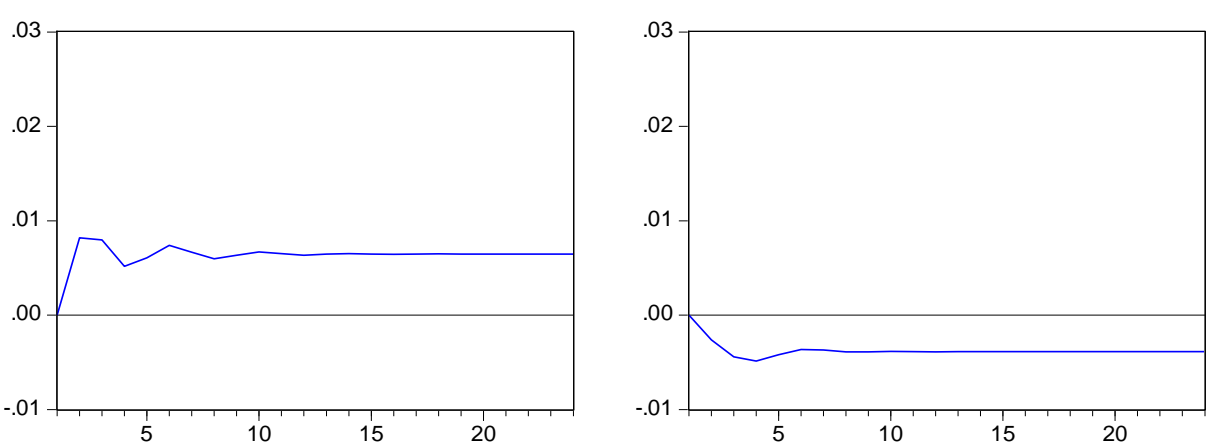

Adapun jika kita melihat Gambar 2. yang merupakan gambaran respon INF (nilai inflasi) terhadap guncangan beberapa variabel KURS dan GOLD, kita dapat mencermati bahwa inflasi merespon positif 0.00I persen terhadap guncangan variabel KURS (nilai mata uang rupiah) sebesar satu standar deviasi. Sedangkan guncangan pada variabel GOLD (nilai emas sebagai proksi variabel dinar) direspon negatif dan permanen oleh INF. Variabel inflasi sebagai indikasi stabilitas ekonomi dari sisi harga dapat dikatakan stabil dalam merespon guncangan KURS setelah periode ke-6, sementara INF mulai stabil dalam merespon guncangan GOLD pada periode ke-I I dengan responsebesar 0.00I persen. Berikut di bawah ini adalah hasil impulse response function untuk respon inflasi terhadap variabel KURS dan GOLD. 


\section{Gambar 2 \\ Respon INF terhadap Variabel KURS dan GOLD}

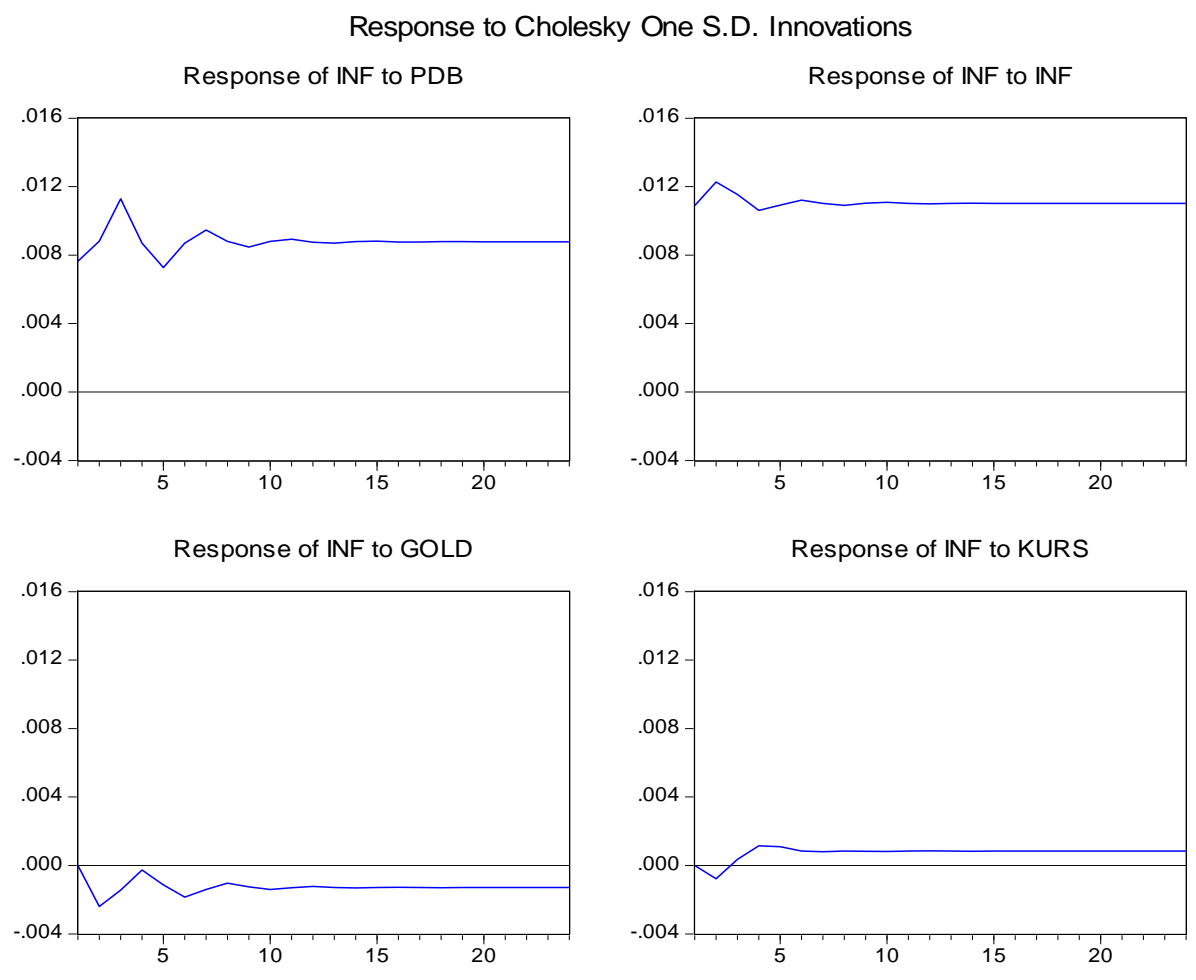

Berdasarkan hasil penting di atas, temuan penting yang dapat diambil simpulan adalah antara lain: Pertama, Variabel KURS sebagai proksi dari nilai tukar rupiah berpengaruh negative terhadap Produk Domestik Bruto Indonesia. Artinya, fluktuasi nilai tukar pada faktanya memang berdampak negative terhadap pertumbuhan ekonomi secara umum. Semakin vulnerable nilai tukar rupiah terutama terhadap dolar, semakin tidak stabil pula pertumbuhan ekonomi yang di dapat. Kedua, berbeda dengan KURS, variabel GOLD yang merupakan proksi dari penerapan dinar (emas) sebagai mata uang, ternyata berpengaruh positif terhadap Produk Domestik Bruto Indonesia. Artinya, penerapan dinar sebagai mata uang yang notabene relatif stabil (bahkan naik), akan mampu mendukung pertumbuhan ekonomi secara umum. Emas yang relatif stabil dan tidak vulnerable, akan mampu memberi dampak positif terhadap perekonomian.

Ketiga, dari perspektif harga-harga barang, variabel KURS berpengaruh positif terhadap tingkat inflasi Indonesia. Artinya, fluktuasi nilai tukar akan berdampak pada meningkatnya tingkat harga secara umum (inflasi). Saat rupiah terdepresiasi, tekanan inflasi di dalam negeri akan meningkat sehingga akan 
mendorong indeks harga konsumen atas barang-barang pokok menjadi naik. Oleh karenanya, penggunaan rupiah yang sangat fluktuatif karena adanya perbedaan intrinsic dan ekstrinsik mata uang menyebabkan ketidakstabilan ekonomi secara umum. Keempat, berkebalikan dengan hasil KURS, variabel GOLD berpengaruh negative terhadap tingkat inflasi Indonesia. Artinya, penggunaan mata uang emas terbukti tidak menyumbang inflasi tapi justru sebagai penahan atau pengendali inflasi. Mengapa hal ini terjadi? Salah satu alasan utamanya adalah karena nilai emas justru lebih stabil dan berada di atas angka inflasi itu sendiri. Temuan ini juga sesuai dengan hasil penelitian Pujiyono (2004), Mursid dan Muklisin (20I3, dan Harahap (20I4) yang merekomendasikan bahwa dinar emas dapat menjadi nilai tukar alternatif.

Iswan (2008) menunjukkan bahwa Indonesia merupakan negara yang memiliki potensi cukup besar untuk menerapkan dinar sebagai alat transaksi perdagangan luar negeri. Selain itu, penggunaan dinar akan memberikan surplus perdagangan dalam bentuk dinar yang akan menjadi cadangan emas Indonesia. Hal ini akan berpengaruh terhadap jumlah mata uang rupiah yang beredar serta nilai rupiah itu sendiri. Dinar emas memiliki fungsi sebagai standar pengukur nilai yang adil. Dinar emas menjamin stabilitas nilai uang dan terciptanya keadilan ekonomi (Pujiyono, 2004; Alhifni dan Trihantana, 2016).

\section{SIMPULAN}

Berdasarkan hasil penelitian yang telah dilakukan mengenai pengaruh penerapan mata uang dinar terhadap stabilitas ekonomi suatu negara, maka diperoleh beberapa kesimpulan, yakni: (I) PDB merespon negatifterhadapguncangan variabel Kurs,sedangkan guncangan padavariabel Gold direspon positif;(2) Inflasi merespon positifterhadapguncangan variabel, sedangkan guncangan padavariabel Golddirespon negatif dan permanen oleh INF.

Penerapan dinar sebagai mata uang yang notabene relatif stabil (bahkan naik), akan mampu mendukung pertumbuhan ekonomi secara umum. Emas yang relatif stabil dan tidak vulnerable, akan mampu memberi dampak positif terhadap perekonomian.Dari perspektif harga-harga barang, variabel Kurs berpengaruh positif terhadap tingkat inflasi Indonesia. Artinya, fluktuasi nilai tukar akan berdampak pada meningkatnya tingkat harga secara umum (inflasi). Saat rupiah terdepresiasi, tekanan inflasi di dalam negeri akan meningkat sehingga akan mendorong indeks harga konsumen atas barang-barang pokok menjadi naik. Variabel Gold berpengaruh negatif terhadap tingkat inflasi Indonesia. Artinya, penggunaan mata uang emas terbukti tidak menyumbang inflasi tapi justru sebagai penahan atau pengendali inflasi. Nilai emas justru lebih stabil dan berada di atas angka inflasi itu sendiri. 


\section{PUSTAKA ACUAN}

Alhifni, A. dan Trihantana, R. (2016). Impact Analysis of The Use of Dinar in Monetart Transaction. Jurnal Syarikah. Vol. 2 (2):267-278.

Gujarati, D. dan Porter, D.C. (2009).Basic Econometrics (5th ed). New York: Mc.Graw Hill.

Hasanah, H.(2007). Stabilitas Moneter pada Sistem Perbankan Ganda di Indonesia.(SkripsiTidak Diterbitkan).Bogor: Institut Pertanian Bogor.

Harahap, D. (20I4). Analisis Stabilitas Dinar Emas dan Dolar AS dalam Denominasi Rupiah. Al-Iqtishad: Jurnal Ilmu Ekonomi Syariah (Journal of Islamic Economics). Vol. 6 (2): 269-282.

Iswan, R.F. (2008). Peluang Dinar Dalam Perdagangan Internasional dan Peluang Pengaruhnya Terhadap Sistem Moneter Indonesia: Suatu Kajian Konseptual. (Skripsi Tidak Dipublikasikan). Jakarta: UIN Syarif Hidayatullah Jakarta.

Mursid, A. dan Muklisin, M. (2013). Ikhtiar Menjadikan Dinar Dirham Sebagai Mata Uang di Indonesia. Equilibrium. Vol. I (2): 258-278.

Pujiyono, A. (2004). Dinar dan Sistem Standar Tunggal Emas Ditinjau Menurut Sistem Moneter Islam. Dinamika Pembangunan. Vol. I (2): I44-I52.

Setiawan, H.(2007) Analisis Faktor Dominan Penyebab Inflasi di Indonesia dan Beberapa Penyelesaiannya Menurut Ekonomi Islam.(Skripsi Tidak Diterbitkan).Bogor: STEI Tazkia 
Penerapan Dinar dan Stabilitas Ekonomi:Pendekatan Vector Autoregression (Aam Slamet Rusydiana) 